\title{
Incentivizing the reduction of pollution at U.S. dairies: Addressing additionality when multiple environmental credit payments are combined
}

\author{
Tibor Vegh ${ }^{*}$ and Brian C. Murray ${ }^{a}$ \\ Duke University
}

Submitted November 8, 2018 / Revised March 28 and August 16, 2019 / Accepted August 28, 2019 /

Published online January 27, 2020

Citation: Vegh, T., \& Murray, B. C. (2020). Incentivizing the reduction of pollution at U.S. dairies: Addressing additionality when multiple environmental credit payments are combined. Journal of Agriculture, Food Systems, and Community Development, 9(2), 123-139. https://doi.org/10.5304/jafscd.2020.092.010

Copyright (C) 2020 by the Authors. Published by the Lyson Center for Civic Agriculture and Food Systems. Open access under CC-BY license.

\begin{abstract}
This article examines the intricacies of environmental credit generation from concentrated animal feeding operation (CAFO) farm systems. Livestock production generates large amounts of manure (solid and liquid waste) and consumes a high volume of water that producers must manage to control odors and reduce pollution. To mitigate environmental impacts such as nutrient releases and greenhouse gas emissions, anaerobic digesters (ADs) can be used in CAFOs to avoid certain nutrient releases and capture the methane $\left(\mathrm{CH}_{4}\right)$ produced when manure is broken down anaerobically. Policy incentives have increased the use of ADs to reduce waste volumes and produce biogas for energy or bioelectricity, but the overall digester adoption rate is still very low (U.S. Environmental Protection Agency [U.S. EPA], 2010; 2014). To cover the higher cost of $\mathrm{AD}$ adoption relative to

a Nicholas Institute for Environmental Policy Solutions, Duke University, Durham, NC 27708 USA.

* Corresponding author: Tibor Vegh, Nicholas Institute for Environmental Policy Solutions, Duke University, Box 90335, Durham, NC 27708; +1-919-613-8721; tibor.vegh@,duke.edu
\end{abstract}

other forms of waste management, farmers may supplement the revenues they generate from the conventional outputs of a livestock operation (e.g., milk or meat) by selling credits into environmental markets. One question that arises is whether a single operation can sell into multiple credit markets by "stacking" credits-that is, receiving multiple separate environmental payments to finance the conversion to $\mathrm{AD}$ technology. The issue is that the use of stacked credits introduces the possibility that some of the stacked credits might be for benefits that are "non-additional" in that they do not produce incremental pollution reductions and thus are suspect for use in offsetting a buyer's pollution. This article describes the stacking problem and explores possible solutions, such as temporal constraints on credit issuance and discounting credits to account for additionality problems.

\section{Keywords}

Ecosystem Service, Anaerobic Digester, Credit Stacking, Carbon, Nutrient, Greenhouse Gas Emissions, Dairy Industry 


\section{Abbreviations Used}

\begin{tabular}{ll}
\hline AD & Anaerobic digester \\
\hline AFO & Animal feeding operations \\
\hline BMP & Best management practices \\
\hline CAFO & Concentrated animal feeding operation \\
\hline CAR & Climate Action Reserve \\
\hline CCA & Clean Air Act \\
\hline CWA & Clean Water Act \\
\hline ELGs & Effluent limitation guidelines \\
\hline ESs & Ecosystem services \\
\hline GHG & Greenhouse gas \\
\hline K & Potassium \\
\hline MRV & Measurement, reporting, and verification \\
\hline N & Nitrogen \\
\hline NMP & Nutrient management plan \\
\hline NPDES & National Pollutant Discharge Elimination System \\
\hline NPSs & Nonpoint sources \\
\hline O\&M & Operating and maintenance \\
\hline P & Phosphorus \\
\hline PSs & Point sources \\
\hline REC & Renewable energy certificate \\
\hline RPS & Renewable portfolio standard \\
\hline TMDL & Total maximum daily load \\
\hline USDA & U.S. Department of Agriculture \\
\hline U.S. GAO & U.S. Environmental Protection Agency \\
\hline WLA & Volatile solids \\
\hline
\end{tabular}

\section{Introduction}

Protein consumption is increasing worldwide, and much of it is produced under some type of concentrated animal feeding operation (CAFO). Making these $\mathrm{CAFO}$ operations more environmentally sound is essential to improving local water and air quality and to mitigating climate change risks. Livestock waste containing nutrients such as nitrogen $(\mathrm{N})$, phosphorus $(\mathrm{P})$, and potassium $(\mathrm{K})$ is typically treated on-site and subsequently applied to the land as a fertilizer. CAFOs, and especially dairies (the focus of this article), are farm systems that produce significant amounts of these nutrients, on the order of 80 pounds ( 80 pounds) of manure, containing 0.45 pounds $(0.20 \mathrm{~kg})$ of nitrogen, and 0.07 pounds $(0.03 \mathrm{~kg})$ of phosphorus, per day for each 1,000pound (454 kg) dairy cow (USDA NRCS, 1992). Nutrient application rates that exceed plant uptake can generate excessive release into waterways, causing serious environmental damage. Various studies have demonstrated that $\mathrm{N}$ and $\mathrm{P}$ in dairy waste can lead to eutrophication problems in ecosystems (Smith, Tilman, \& Nekola, 1999). Decomposing manure also emits methane $\left(\mathrm{CH}_{4}\right)$, a greenhouse gas (GHG) with approximately 25 times the 100-year global warming potential of carbon dioxide ( $\left.\mathrm{CO}_{2}\right)$ (Myhre et al., 2013). It also emits ammonia $\left(\mathrm{NH}_{3}\right)$ and hydrogen sulfide $\left(\mathrm{H}_{2} \mathrm{~S}\right)$, which contribute to localized air pollution. Thus, manure management at CAFOs has an effect on climate and the environment through changes in GHG emissions and air and water quality.

To lessen environmental impact, CAFOs need to meet water and, potentially, air quality standards under the Clean Water Act (CWA; 33 U.S.C. \$1251 et seq., 1972) and Clean Air Act (CAA; 42 U.S.C. $\$ 7401$ et seq., 1970). For compliance, CAFOs have been employing various technologies to reduce contaminants in their waste streams. These treatment methods include both aerobic (with oxygen) and anaerobic (without oxygen) processes and the filtration of wastes in wetlands (Arvanitoyannis \& Giakoundis, 2006).

Anaerobic digesters (ADs) can be used in CAFOs to capture the methane produced when manure is broken down anaerobically. Policy incentives, primarily through voluntary adoption with cost-share or other forms of subsidy, have increased the use of this relatively mature technology to reduce waste volumes and in some cases to produce biogas for energy with the captured methane, but the overall digester adoption rate is still very low (U.S. EPA, 2018).

To cover the higher cost of AD adoption relative to other forms of waste management, farmers may supplement the revenues they generate from the conventional outputs of a livestock operation (e.g., milk or meat) by attempting to sell credits into multiple environmental markets. If they use the captured biogas to produce electricity on-site, they may be able not only to reduce their own onsite energy costs or sell power to the electrical grid, but also to sell renewable electricity certificates (RECs) to buyers seeking credit for using renewable power.

Another possible revenue source is GHG 
credits, also known as carbon credits, and nutrient credits are examples of products sold in environmental markets that could help livestock producers cover the cost of installing and operating ADs. These credits, as described further below, can be used as marketable "offsets" that buyers can use to help meet their GHG reduction goals, renewable energy goals, nutrient pollution reduction goals (either regulatory or voluntary), or all of the above. One issue that arises is whether a single operation can sell into multiple credit markets by "stacking" credits. Stacking refers to receiving multiple environmental payments to finance the conversion to AD technology. A critical issue with credit stacking is whether it can be done without violating "additionality" criteria (Robertson et al., 2014). Additionality ensures that environmental credits generated by a project represent emission or pollution reduction relative to a business-as-usual scenario. In other words, a reduction that would not have occurred in the absence of said project is said to be additional to the status quo. Environmental credit markets typically seek to pay only for additional pollution reductions below some baseline level, making violations of additionality problematic from the perspective of the project's financial viability (Verified Carbon Standard, 2013).

Currently, no public policy addresses environmental credit generation in these farm systems, or in any other system in which multiple credits could be generated. The ambiguities that result from the lack of regulation, rules, or guidance might prevent some operators from adopting an AD system in their operations.

Clearly, multiple payments can increase revenues and thus increase the attractiveness of the $\mathrm{AD}$ investment. However, the use of stacked credits also introduces the possibility that some of the stacked credits might be for benefits that are "nonadditional" in that they do not produce incremental pollution reductions and thus are suspect for use in offsetting a buyer's pollution. This article informs the development of environmental credit markets by (1) explaining various forms of stacking, such as horizontal, vertical, and temporal, and (2) describing when stacking would be acceptable and when it would be problematic.

This article explains the issues of how the dynamics of environmental credit programs can affect the intended environmental outcomes, which may help address issues stemming from CAFO systems that generate stacked credits. It offers background information on CAFO waste handling systems, types of pollution generated, and types of environmental payment options for CAFOs. It further identifies which types of incentives are and are not needed to induce AD adoption, and how rules for additionality and stacking affect these incentives in these farm systems. This information could be the basis for identifying the roles that government agencies such as the U.S. Department of Agriculture (USDA) may be able to play in establishing market standards or in gathering the data necessary to support standards not imposed by government. Although the focus is on technology, market, and institutional factors affecting environmental crediting from $\mathrm{AD}$ adoption at dairies in the United States, the issues addressed are relevant for a wide range of ecosystem service markets that arise in countries throughout the world.

\section{Data Sources and Methods}

No federal agency collects consistent and reliable data on CAFOs, which makes it challenging to credibly determine how many there are in the U.S. (Miller \& Muren, 2019; U.S. GAO, 2008). An analysis of historical farm trends shows that a reasonable range in the number of operations of dairy CAFOs in the U.S. is somewhere between 2,700 and 4,300 (U.S. GAO, 2008). This number aligns very well with more recent data from the 2012 Census of Agriculture that shows 3,464 dairy operations with more than 500 head of livestock (USDA, 2019). These large dairy CAFO operations represent about $60 \%$ of the U.S. animal inventory, or 10.8 million dairy cows (USDA, 2019).

We assessed the environmental impacts of these CAFO operations as a snapshot for 2015 through a literature review focusing on nutrients, GHG emissions, and various manure treatment technologies. We calculated the prevalence of $\mathrm{AD}$ technology adoption at operating CAFOs based on U.S. EPA (2014) data and the AgSTAR database, which provides information on anaerobic digester projects on livestock farms in the U.S. The costs of AD installation and operation were based on ICF 
(2013), adjusted to the year of analysis, 2015, using the federal Consumer Price Index (U.S. Bureau of Labor Statistics, n.d.).

\section{Current Public Policy on Waste Management in CAFOs}

Animal feeding operations (AFOs) are defined by the U.S. EPA (40 C.F.R. $\int 122.23,2014$ ) as feeding operations in which animals have been, are, or will be stabled or confined and fed or maintained for a total of 45 or more days in any 12 -month period, and in which crops, vegetation, forage growth, or post-harvest residues are not sustained in the normal growing season over any portion of the lot or facility (U.S. EPA, 2008a). A CAFO is defined as an AFO that is large (e.g., 700-plus dairy cows), medium size (e.g., 200-699 dairy cows), or a significant contributor of pollutants to U.S. waters (U.S. EPA, 2008a).

\section{U.S. Environmental Regulations Relevant to CAFOs} CAFOs were identified as point sources of pollution in Section 502 of the CWA. The CWA, through the National Pollutant Discharge Elimination System (NPDES) permit program (CFR Title: 40, 122.23(b)(1), 1990), sets effluent limitation guidelines (ELGs) and standards for certain pollutants from CAFOs. The CWA specifically mentions CAFOs, which are considered point sources under the act. In recent years, the U.S. EPA has increased the regulation of CAFOs, especially those operating anaerobic lagoons for waste management. After a series of changes, the final 2008 CAFO rule requires CAFOs to apply for permits if they discharge waste and nutrients into waterways (U.S. EPA, 2008). Along with the permit application, CAFOs that discharge waste must also develop a nutrient management plan (NMP), which is a tool for managing $\mathrm{N}$ and $\mathrm{P}$ through best management practices (BMPs) to meet effluent limitations and standards. The CAFO rule states that producers must calculate their nutrient release either in terms of pounds of nutrient per acre (i.e., using the linear approach), or the amount of wastewater (i.e., using the narrative rate approach). In either case, an annual report must be filed with release estimates. Overall, there is evidence that the enforcement of both water and air quality regulations relevant to CAFOs has been very limited to date (Hoover, 2013; Merkel, 2006; U.S. GAO, 2008).

\section{Wastewater Properties and Management}

Livestock waste management operations systems address manure production, environmental residuals, processing, and resource recovery. This article focuses on dairy CAFOs and describes conventional manure management processes and material flows of waste management (Figure 1). The specifics vary by type of livestock, operation size, and geographic location, but waste management processes include some or all of the following: flushing of waste, recycling of wastewater, waste storage, and pumping, digestion of waste, waste spreading, and solids separation and handling. Solids can either be composted or put through the optional anaerobic digestion process, which yields soil amendments and bedding, biogas, and liquids containing nutrients. Liquids gathered either in solids separation or as outflow from the $\mathrm{AD}$ can be used for process water, applied to the land, or put through nutrient removal processes that yield irrigation water, fertilizer, or products used for industrial purposes. Conventional methods of storage before land application vary across CAFOs and may include anaerobic lagoons, roofed storage sheds, storage ponds, underfloor pits, or above- or below-ground storage tanks (USDA NRCS, 1992). Of these methods, anaerobic lagoons tend to be the least expensive and, therefore, are often used in the management of wastewater (Pfost \& Fulhage, 2000).

Pollutants associated with dairy manure management include the nutrients phosphorus and nitrogen (in the forms of nitrous oxide and nitrate, and ammonia); hydrogen sulfide; particulate matter $\left(\mathrm{PM}_{\mathrm{x}}\right)$; and the GHGs methane, nitrous oxide, and carbon dioxide. When manure is land applied, its properties affect soils, ground and surface water quality, and air quality from local to global scales. Some nutrients, such as nitrogen, are recyclable through plants, whereas others, like salts (sodium or chlorine), are not and can have adverse effects on soils if applied in excess. From an environmental perspective, nitrogen, phosphorus, potassium, volatile solids (VSs), and salinity are the wastewater properties of most interest. 
Figure 1. Process and Material Flow Diagram of Dairy Manure Management

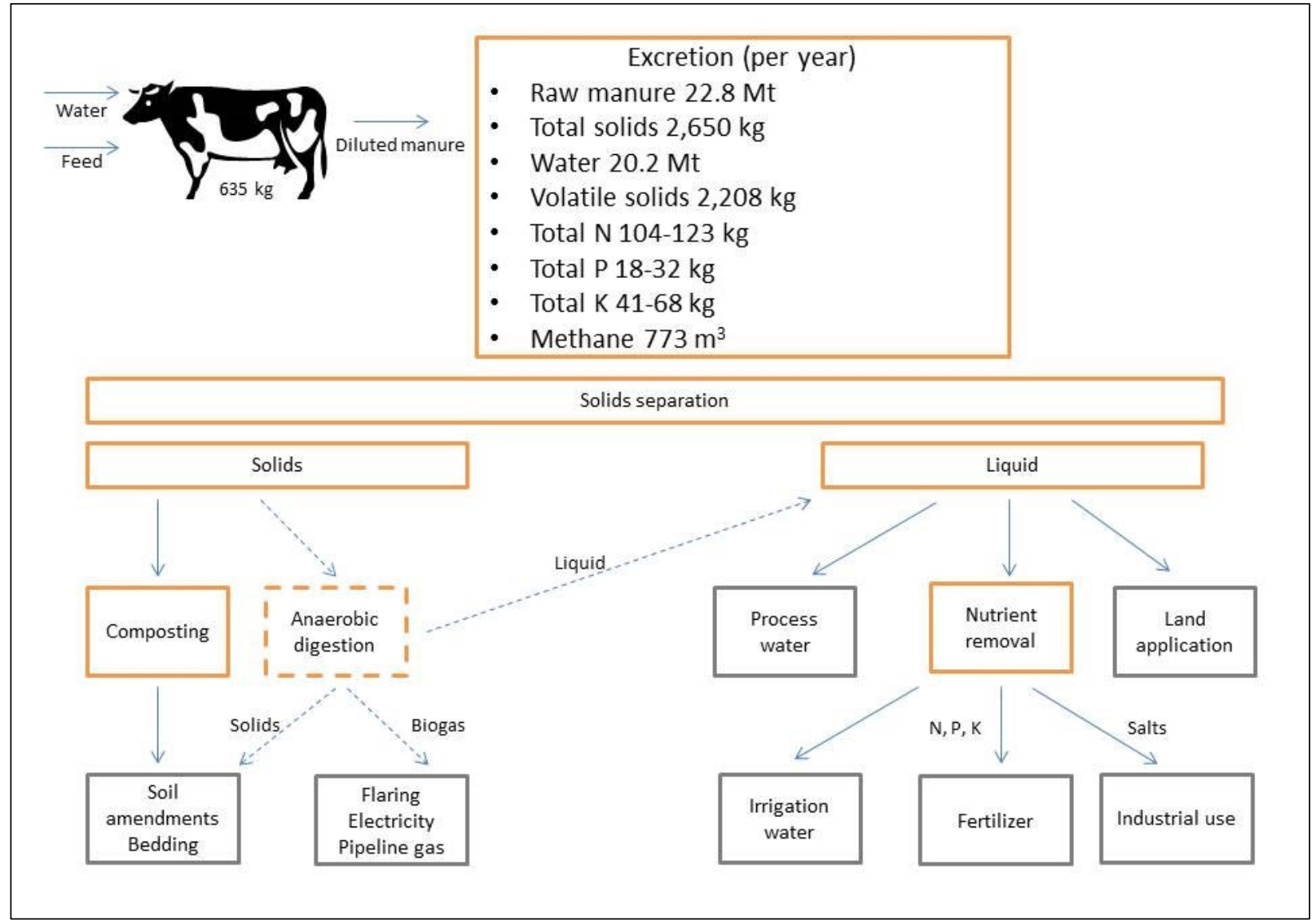

Note: Grey boxes represent process outputs, arrows represent material flows, and dotted lines show material flows that are not part of conventional manure management. Dairy manure characteristics per cow are shown for a typical $635 \mathrm{~kg}(1,400$ pound) lactating dairy cow. Source: Van Horn, Wilkie, Powers, \& Nordstedt, 1994.

\section{Anaerobic Digestion}

During the AD process, bacteria break down organic material in the absence of oxygen and produce biogas, which contains $55-70 \%$ methane, $30-45 \%$ carbon dioxide, and other trace gases (Lazarus, 2008). The methane created in the AD process can be captured and either flared to produce carbon dioxide (a less potent GHG) or used as energy that can supplant fossil fuels (Murray, Galik, \& Vegh, 2017). ADs thus have received attention for their potential to mitigate GHG emissions. However, with proper design, ADs have been shown to not only capture methane, but also have the potential to assist in odor control, reduce air and water quality degradation, and increase nutrient management flexibility, thereby generating environmental benefits in addition to reduced GHGs (Lazarus, 2008; Yiridoe, Gordon, \& Brown, 2009).

\section{Technology and Economics}

The components of an $\mathrm{AD}$ include the digester vessel, manure handling system, gas handling and use system, and manure storage tank. Several types of ADs exist (Table 1), but the most widely used ADs in dairy systems are plug flow, complete mix, covered lagoon, and fixed film (Lazarus, 2008, Table 1, p. 9). The type of AD used depends on manure qualities (e.g., liquid, slurry). Free-stall dairy operations with daily-scraped alleys work well with ADs because the manure does not get mixed with dirt or stones and is moved into the digester while fresh. However, drylot dairies, beef, sheep, and poultry operations are not compatible with ADs 
Table 1. Anaerobic Digester Types and their Prevalence among Dairies with Operating Digesters

\begin{tabular}{lllll}
\hline \multicolumn{2}{c}{ Plug flow } & \multicolumn{1}{c}{ Complete mix } & \multicolumn{1}{c}{ Covered lagoon } & \multicolumn{1}{c}{ Other } \\
\hline Description & $\begin{array}{l}\text { A long, narrow concrete } \\
\text { tank with a rigid or } \\
\text { flexible cover }\end{array}$ & $\begin{array}{l}\text { An enclosed, heated } \\
\text { tank with a mechanical, } \\
\text { hydraulic, or gas mixing } \\
\text { system }\end{array}$ & $\begin{array}{l}\text { An anaerobic lagoon } \\
\text { sealed with a flexible } \\
\text { cover }\end{array}$ & $\begin{array}{l}\text { Induced blanket reactors } \\
\text { (IBRs) develop a blanket of } \\
\text { sludge that retains anaerobic } \\
\text { bacteria; fixed-film digesters } \\
\text { contain plastic media which } \\
\text { bacteria attach to and grow }\end{array}$ \\
Manure type & $\begin{array}{l}\text { Works well for scrape } \\
\text { manure management } \\
\text { systems for semi-solid } \\
\text { manure }\end{array}$ & $\begin{array}{l}\text { Designed to handle } \\
\text { slurry manure } \\
\text { effectively }\end{array}$ & $\begin{array}{l}\text { Used for flush or } \\
\text { dilute manure in } \\
\text { warm climates }\end{array}$ & $\begin{array}{l}\text { IBRs works best with highly } \\
\text { concentrated waste; fixed- } \\
\text { film technology is suitable for } \\
\text { diluted waste }\end{array}$ \\
Prevalence (\%) & 53 & & 10 & 5 \\
\hline
\end{tabular}

Sources: North Carolina Cooperative Extension, 2012; U.S. EPA, 2014b; U.S. EPA AgSTAR, 2018.

because the manure may decompose before it is scraped.

In 2009, the U.S. Secretary of Agriculture set a target to reduce GHG emissions from dairy operations by $25 \%$ before 2020 , using ADs as the primary method for meeting this goal (USDA, 2009). Though costs have been falling steadily over time, $\mathrm{AD}$ adoption rates have been low due to the high upfront capital and operating and maintenance $(\mathrm{O} \& \mathrm{M})$ cost requirements. Of the approximately 3,464 dairy CAFOs with more than 500 animals in the U.S. (USDA, 2019), only 282 (8\%) have ADs (U.S. EPA, 2019). A U.S. EPA AgSTAR report has identified 500 dairy cows or 2,000 head of swine as the minimum for which an $\mathrm{AD}$ is likely to provide positive financial returns, but this threshold depends on the cost of alternative (fossil) fuel sources for electric power generation, a factor made more relevant by the recent substantial decline in natural gas prices (U.S. EIA, 2016). Based on available data (ICF, 2013), adopting an $\mathrm{AD}$ in a 500-animal dairy $\mathrm{CAFO}$ requires an upfront capital investment of US $\$ 600,000$ - US $\$ 875,000$ to construct the digester unit itself and an additional US $\$ 110,000$ US $\$ 160,000$ annually for operation and maintenance. For an average size operation $(n=2,394$, U.S. EPA, 2014), the capital costs of a covered lagoon, complete mix, or plug flow digester are in the range of US $\$ 1.6$, US $\$ 1.8$, and US $\$ 2.2$ million 2014 inflation-adjusted (U.S. BLS, 2014), respectively (ICF, 2013). A report on digester economics in the state of California, the largest dairy producer in the United States, concluded that the costs of building an AD typically outweigh the benefits (revenue) if ecosystem services (ESs) are not priced (Lee \& Sumner, 2014). As described above and elaborated on below, these ESs can be priced through a credit program and can include carbon credits, nutrient reduction credits, and-if the AD is producing renewable energy-RECs.

\section{Potential for Pollution Reductions}

\section{Methane emissions reductions}

According to ICF (2013), methane generation and capture per dairy cow are approximately 582 to 690 $\mathrm{m}^{3}$ /year/animal (384 to $455 \mathrm{~kg} /$ year/animal), depending on the type of AD. Different types of digesters allow for varying degrees of substrate breakdown and capture. If the manure of all 10.8 million cows in large CAFOs (USDA, 2019) were treated in an $\mathrm{AD}$, the potential amount of methane emission reductions, depending on $\mathrm{AD}$ type, are 3.6 to $4.2 \mathrm{MMt}$ methane/year, assuming an $85 \%$ collection efficiency (CAR, 2009). This is equal to $13.6 \%-16.0 \%$ of U.S. methane emissions in 2016a carbon dioxide equivalent of 90 to $105 \mathrm{MMt}$ carbon dioxide equivalent per year or the subtraction of some 14 million cars off U.S. roads. However, these numbers are not counted against a baseline, which in this case would be an aerobic or anaerobic conventional manure management system with positive emissions. 
Nitrogen, Phosphorus, and potassium reductions

Relative to conventional manure management systems, ADs do not change the amount of nutrients in the waste stream and do not significantly reduce manure volume. In fact, anaerobic digestion does not reduce the mass of total nitrogen and phosphorus within the waste stream; it only mineralizes organic nitrogen and phosphorus to inorganic forms, ammonia, and phosphate, respectively. Ammonia can be converted to nitrate for plant uptake and is preferred for minimizing nitrogen leaching losses.

As part of a conventional manure management system, solids separation can remove $10 \%-20 \%$ of nitrogen and $5 \%-20 \%$ of phosphorus (Frear, 2012), and this process can be part of an AD operation. Dedicated nutrient recovery systems and methods such as micro-screens, centrifuges, polymer flocculation, nitrification/denitrification, ammonia stripping, and struvite can help extract additional nitrogen and phosphorus from waste effluent with varying efficiency (Ma, Kennedy, Yorgey, \& Frear, 2013). These technologies traditionally are not used at CAFOs but are being developed and tested as post-processors of ADs for the expressed purpose of reducing nutrients from the effluent, typically for land application in lieu of fertilizers. According to one industry source, current nutrient recovery technology can achieve effluent nitrogen recovery rates of $40 \%$ and phosphorus recovery rates of $80 \%$ (Informa Economics, 2013). These rates are equivalent to $0.1-13 \mathrm{~kg}$ nitrogen and $0.04-0.07 \mathrm{~kg}$ phosphorus/cow/day. A more recent study claims that current technology is capable of removing $98.3 \%$ of nitrogen, $100 \%$ of phosphorus, and $99.15 \%$ of potassium, from the effluent, which could result in large credit generation potential, depending on these rates compared to regulatory requirements and baseline practices (Douglas, 2012). Whether a nutrient recovery system is installed postdigestion or as a standalone operation in a conventional system depends on various factors, such as whether the nutrient reduction benefits justify the additional costs of adding the nutrient recovery system. The monetization of nutrient reduction benefits will be affected by the dairy operators' ability to sell nutrient reduction credits.

\section{Adoption Economics}

Because $\mathrm{AD}$ is a costly addition to conventional waste management systems, with or without an additional nutrient recovery system, dairy operators need some economic or regulatory reason to cover an AD's costs and incentivize adoption. The upfront cost of $\mathrm{AD}$ adoption has been a large obstacle yet to be overcome at scale, even with the availability of numerous funding mechanisms; it will be a larger obstacle if nutrient recovery systems are added (U.S. EPA, 2012). Funding for the construction of ADs may come from grants, loan guarantees, or similar funding mechanisms. Although these subsidies can be useful in covering up-front costs, the focus of this article is on the potential for $\mathrm{AD}$ to generate economic value beyond the core commodity outputs (e.g., milk or meat).

\section{Value Stream from Bioenergy Production}

One potential revenue source from $\mathrm{AD}$ is from the on-site generation of biogas or electricity that can be sold into energy markets or used to reduce onsite energy costs (Murray et al., 2015). One question producers might face is whether to use the biogas produced on-farm to produce power on-site or to ship off-farm as piped biogas, assuming such a connection to the system is feasible. Broader energy market trends, specifically those in the natural gas market, have a large influence on biogas markets and affect how producers use the biogas captured in ADs. Pipeline biogas, a substitute for natural gas, may be competitive with the on-site generation when natural gas prices are high, which does not describe the current reality (in 2019), but could if prices increased due to restrictions in supply or increases in demand. Another potential source of revenues could come from environmental markets that buy pollution reduction credits, as described below.

Revenue from Credits Sold in Environmental Markets Other potential revenue sources to finance AD adoption are from environmental markets, particularly those for GHG reduction offset credits, RECs, and nutrient reduction credits. These credits and certificates can be sold to other entities seeking compliance with regulatory mandates (e.g., renewable portfolio standards now in place in approxi- 
mately 30 U.S. states [Barbose, 2018]) or to voluntary buyers. These markets are in various stages of development, and several areas of ambiguity remain.

\section{GHG Credits}

When the conventional CAFO waste management technology without $\mathrm{AD}$ adoption is an anaerobic technology (e.g., lagoon storage of wastes), it generates emissions of methane, a greenhouse gas. As discussed above, ADs can provide a way of reducing methane emissions by decomposing the manure in the digester. Though GHGs have been the subject of regulation in the U.S at the federal level for over a decade, specific regulations to achieve reductions have lagged. ${ }^{1}$ Meanwhile, GHGs have been regulated in 10 U.S. states. While agriculture is not likely to be a directly capped source under federal or state programs in the foreseeable future, emissions reductions from $\mathrm{AD}$ adoption could, in principle, be used to generate GHG offsets for those facilities that are facing GHG regulation. This is now the case under the current cap-and-trade law controlling GHGs in California. These reductions could also enter into a voluntary market for emissions reductions without a regulatory inducement.

The generation of such GHG reduction credits is typically verified by third-party organizations, registered by a voluntary registry, or used for compliance (e.g., in the California market) after the appropriate conversion of methane credits to carbon credits, based on the higher global warming potential of methane relative to carbon dioxide.

In the U.S., the California compliance carbon market and voluntary carbon markets have published protocols that describe how ADs can generate credits only if an anaerobic system, such as an anaerobic lagoon, was in place prior to the adoption of AD technology. The reason for this is that methane is not generated in aerobic systems, and thus installing an AD on an aerobic system would increase methane production rather than reduce emissions below the status quo.
Other requirements of protocols also affect ADs. For instance, the Regional Greenhouse Gas Initiative (RGGI, 2013), which regulates power plant emissions in nine Northeastern U.S. states, declares that GHG offsets cannot be generated if the offset project has an electric generation component, unless the legal right to credits is transferred from the project sponsor. This caveat would apply to ADs regardless of size.

\section{Renewable Electricity Certificates}

RECs represent environmental and other nonpower attributes of renewable electricity generation, but not the electricity itself (U.S. EPA, 2008b). This definition has been referenced as the conceptual basis for RECs, including GHG benefits (one attribute of renewable electricity), and might by itself suggest that RECs and GHG credits should not be sold separately. There has been an ongoing debate about this issue, however. For example, according to North Carolina's NC Senate Bill 3, GHG effects are not included in RECs (North Carolina General Statutes \62-133.8(a)(6), [2014]). Specifically, the statute states that "A 'renewable energy certificate' does not include the related emission reductions, including, but not limited to, reductions of sulfur dioxide, oxides of nitrogen, mercury, or carbon dioxide" (para. \# 6). Thus it would appear that legislation such as this, which separates GHGs from other environmental attributes inherent in RECs, can override any presumed restriction on the separation of a GHG credit and an REC.

To others, such as the U.S. EPA, a REC represents one megawatt-hour of renewable electricity and the right to claim the attributes (benefits) of the renewable generation source for only one buyer. Specifically, the EPA states that a REC represents the environmental, social and other non-power attributes of renewable electricity generation (U.S. EPA, 2019b). Therefore, the debate over exactly what attributes a REC does and does not include remains unresolved, and no oversight from government or independent parties currently

\footnotetext{
${ }^{1}$ At the federal level, GHGs are deemed a pollutant to be regulated by the U.S. EPA under the Clean Air Act, but recent federal efforts to regulate GHGs have been tied up in legal and political combat, including a federal cap-and-trade program that failed to clear the U.S. Congress in 2011 and the Trump administration's reversal of GHG caps on the electric power sector in 2017.
} 
exists. It is thus important to pay attention to the governing laws of the system in which RECs are sold.

State renewable portfolio standards (RPSs) require a certain percentage of the electric power to be supplied by renewable sources such as wind, solar, and bioenergy. RECs are generated by renewable electricity producers and are used by power utilities to collectively meet their renewable generation requirements under state RPSs. Renewable power producers thus produce two distinct commodities: undifferentiated electricity (renewable power that has the same physical characteristics as non-renewable power) and RECs. They can sell the power into the grid like any other producer, but they sell RECs into a separate commodity market. The buyers in the REC commodity market are the power companies in states that are obligated to meet the RPS target. A company is compliant if the ratio of RECs to total generation equals the RPS target. ${ }^{2}$ In some cases, there are special "carveouts" for specific types of power. For instance, in North Carolina, the RPS target is $12.5 \%$ by 2021 for investor-owned utilities $(10 \%$ by 2018 for cooperatives and municipalities), but $0.2 \%$ of power must be met by bioenergy from swine operations and 900,000 MWh from poultry waste, both of which are tied to AD production methods, illustrating how major agricultural producer states can put in place particular incentives based on their own situation.

Wherever the electricity produced from methane through the $\mathrm{AD}$ process qualifies under an RPS, digester operators can sell RECs at the actual market price separately from the actual electricity. Conventional manure management systems typically do not produce electricity or biogas, because methane collection is difficult without an AD. The producer who does produce power using biogas from an AD system typically signs a power purchase agreement with a utility company to sell the generated electricity, which is equal to the total renewable electricity production in the $\mathrm{AD}$. Alternatively, the producer can use the electricity onfarm to run equipment and reduce operating costs.

\section{Nutrient Credits}

In 2003, the EPA issued a Water Quality Trading Policy that stipulated the conditions under which water quality trading could be used to meet compliance with total maximum daily load (TMDL) limits for nutrients $(\mathrm{N}$ and $\mathrm{P})$ and sediments (U.S. EPA, 2003). Under these provisions, regulated sources of these pollutants, in principle, can engage in nutrient trading to meet the loading requirements more cost-effectively. Nutrient credit trading is defined as the sale of a unit of nutrient credit that was generated by a source as a result of nutrient reduction below that source's permit limit that the buyer can use to compensate for its own exceedance of that limit by a corresponding amount. Agriculture operations are typically considered nonpoint sources (NPSs), which include all sources and means other than direct discharges from point sources (PSs), by which pollutants may end up in water bodies.

In the case of $\mathrm{ADs}$, the regulatory process for credit calculation is conceptually straightforward but can be difficult in practice (Douglas, 2012). CAFOs and ADs are distinct from other agricultural activities in that they are regulated point sources under the CWA and can discharge no more than their waste load allocation (WLA), which is included in their NPDES permit. CAFOs are required to be "zero discharge" for the production area itself per 40 CFR 412, but CAFOs are still assigned a WLA because of possible overflows from the production area. However, by installing an $\mathrm{AD}$ to digest manure, and a dedicated nutrient recovery system to remove nutrients, the $\mathrm{CAFO}$ may earn PS nutrient credits by reducing nutrient outflows to below that specified on its NPDES permit. Thus, the credit is calculated as the amount of pollution reduction below the CAFO's permit limit, or:

$$
\text { Credit }=W L A_{\text {without } A D}-W \text { aste Load with } A D
$$

Nutrient credit trading can take one of three forms: (1) credits generated by PSs available for sale or transfer to other PSs for regulatory compliance; (2) credits generated by PSs and NPSs for

\footnotetext{
${ }^{2}$ Power producers in states facing an RPS are typically allowed to use RECs that are generated in other states, as long as the credits are verified and have cleared a registry to ensure that they are only used once in any state.
} 
regulatory compliance for PSs; or (3) credits generated by PSs and NPSs sources for regulatory compliance for both PSs and NPSs. ADs regulated as point sources under the CWA can best take advantage of nutrient credit markets in the third scenario because of higher credit prices due to higher demand.

\section{Baselines and Additionality}

Two of the environmental credit markets of interest in this article-nutrients and GHGs, but not RECs - generally seek to pay only for additional pollution reductions below some baseline level. The fundamental calculation for a pollution reduction (offset) credit can be expressed:

$$
\text { Credit }=\text { Baseline pollution }- \text { Pollution with } A D
$$

Nutrient Baseline $=W L A$. "Baseline" pollution refers to the pollution expected from an operation if standard operating practices are followed and, in the case of water pollution, mandated nutrient load allocations are met. For example, the baseline level of nutrient pollution for a CAFO is its WLA specified on its NPDES permit. Because nutrient loads from CAFOs are regulated-although monitoring of nutrient pathways in the effluent for land application, or monitoring of water quality on-site is not required — the only additionality requirement for nutrient crediting is that the waste load with $\mathrm{AD}$ be below the WLA, as discussed in the previous section and defined in Equation 1.

GHG Baseline Alternatives. For other pollutants that are not directly regulated at CAFOs, such as GHGs, baseline determination is more complicated. In principle, it is the quantity of that pollutant generated under current conventional management practices, which include practices at similarsize operations in a similar location. If a comparable cohort is not available, or if a new facility is being considered, there are several alternative ways to define a baseline, as described below.

In principle, crediting occurs when emissions are reduced below the baseline, as long as the action is deemed additional to what otherwise would have occurred under business-as-usual circumstances. In practice, the application of base- lines and additionality principles can be complicated. In environmental markets, four forms of additionality are typically considered (World Resources Institute [WRI], 2014):

- Regulatory additionality refers to environmental benefits beyond those required by law;

- Temporal additionality refers to new practices implemented after a certain point in time;

- Performance standard (also known as "baseline") additionality establishes a performance standard above which the adopted action is considered a material improvement over business as usual; and

- Financial additionality means that projects would not have occurred without the revenue provided by a crediting market or program.

Using the Climate Action Reserve (CAR) protocols for GHG credits as examples, there are dual additionality requirements: (1) regulatory additionality, using a legal requirement test; and (2) a performance standard. In the case of an $\mathrm{AD}$, the legal requirement test would find that there are no laws, statutes, regulations, or mandates requiring the installation of an AD in livestock operations (CAR, 2013a) or that limit GHGs from CAFOs in any way. The performance standard test would require detailed analysis, including baseline emissions modeling and calculating projected methane emissions, the difference of which is the number of credits calculated.

Temporal additionality is fairly straightforward in that it sets a date certain after which payments would be deemed non-additional. The financial additionality criterion, though not used by CAR, could be used in other future protocols, and we argue is the most relevant criterion to the issue of credit stacking. Financial additionality tests whether or not a project is financially viable when all sources of revenue, excluding revenue from environmental markets, are considered. The underlying question is whether stacking leads to a situation in which some projects would be financially viable with some but not all of the credits being issued. 
Therefore, the financial additionality criterion is met for an environmental credit stream in question if, absent that stream (and including all other revenue sources, including other environmental credits), the project is not financially viable.

The stacking of environmental market credits allows producers to receive payments for multiple ecosystem services generated by a new project or practice, such as $\mathrm{AD}$ adoption. In the case of a CAFO, stacking can take four forms (WRI, 2014):

- Horizontal: Different environmental credits issued for different projects on the same property.

- Vertical: Different environmental credits issued for one project.

- Temporal: Different environmental credits issued over time.

- Payment: Combining other forms of finance (e.g., government cost-share programs) with environmental credits.

From a financial additionality standpoint, the least concerning for a CAFO is horizontal stacking, because each project, if fully independent, should have its own distinct set of financial and additionality requirements. Consider a large farm that plants trees to sequester carbon for GHG credits, uses best cropland management practices to reduce $\mathrm{N}$

Table 2. Hypothetical Example of the Impact of Credit Stacking on the Profitability of AD Adoption

\begin{tabular}{ll}
\hline Revenue Stream & NPV of AD Adoption \\
\hline Ag commodities only & Negative (unprofitable) \\
\hline Ag commodities & Negative (unprofitable) \\
Bioenergy revenues (or cost reductions) & \\
\hline Ag commodities & Negative (unprofitable) \\
$\begin{array}{l}\text { Bioenergy revenues (or cost reductions) } \\
\text { RECs }\end{array}$ & \\
\hline Ag commodities & \\
Bioenergy revenues (or cost reductions) & Positive (profitable) \\
$\begin{array}{l}\text { RECs } \\
\text { Nutrient credits }\end{array}$ & \\
\hline Ag commodities & Positive (profitable) \\
Bioenergy revenues (or cost reductions) & \\
RECs & \\
Nutrient credits & \\
GHG credits &
\end{tabular}

runoff, and adopts an AD to manage CAFO wastes and possibly generate GHG credits. Each of these projects stands on its own and should present no additionality problems if all credits on the separate projects go to one landowner.

Vertical stacking and temporal stacking create potential financial additionality issues for CAFOs with $\mathrm{ADs}$. That is because the $\mathrm{AD}$ system with dedicated nutrient removal and bioelectricity generation can potentially supply GHG and water quality credits as well as RECs, and it is possible that credits from a subset of those activities would provide sufficient incentives for adoption, leaving the remaining credits unnecessary-and, in principle, non-additional as described above. The environmental value of such non-additional credits is zero since they represent no additional environmental benefits from the project, and attributing positive values to them is equivalent to overestimating the true amount of pollution reduction these credits represent. Similarly, payment stacking of multiple sources of funding for the same project is also concerning, because financial additionality in each environmental market or other funding sources may be affected.

\section{Stacking, Baselines, and GHG Additionality under} an AD's Joint Production of Pollution Reduction

ADs with nutrient recovery can generate multiple forms of pollution reduction jointly, meaning roughly in fixed proportions at the same time. This reality complicates the notion of a baseline, especially when, by stacking, the $\mathrm{AD}$ operation is simultaneously paid for by RECs, GHG credits, and nutrient credits-or two of the three-raising the financial additionality issues just described.

The joint-production-stacking example can be shown by the hypothetical example in Table 2, which shows the profitability of $\mathrm{AD}$ adoption under five scenarios, ranging from a single revenue stream from conventional agricultural commodities (e.g., milk and meat from a dairy) to multiple revenue streams from agricultural commodities, bioenergy, RECs, nutrient credits, and GHG credits. 
Table 2 shows that adoption becomes profitable once the nutrient credits are added to the stack, which alone might suggest that an $\mathrm{AD}$ with revenues from agricultural commodities, bioenergy, RECs, and nutrient credits is a viable economic proposition. If so, it could be asserted that the availability of these revenue streams creates a "new baseline" (see equation at the top of this section) against which the generation of GHG credits would be evaluated. This new baseline could, in principle, place some restrictions on the stacking of nutrient credits on top of the other credits. Establishing such a baseline would require coordination among multiple environmental credit markets or at least the development of joint protocols to use for the measurement, reporting, and verification (MRV) of multiple environmental credits. For instance, because nutrient reduction would be presumed to occur under the new baseline for GHG crediting, it could be argued that no GHG credits should be issued given that no additional reductions are being induced by the inclusion of GHG credits. The reasoning is that the buyer of a GHG credit would be given the right to emit a corresponding quantity of GHGs elsewhere. Thus, if the credited action is not associated with a real reduction, the exchange would effectively allow pollution to increase rather than to attain pollution neutrality as intended.

Alternatively, if the AD investment in Table 2 were determined not to be profitable with the nutrient credits in place, the additionality of the GHG credit stack would not be as questionable. Presumably, the GHG payments would be necessary to adopt $\mathrm{AD}$ and produce the corresponding level of GHG reductions (and nutrient credits, RECs, and electricity).

Stacking over time. Now consider stacking over time. In the Table 2 example, $\mathrm{AD}$ adoption might be expected to occur if the first four revenue streams (commodities, energy sales, RECs, and nutrient credits) can be stacked, because the NPV of adoption is positive. However, if GHG crediting becomes available a couple of years after AD adoption at a specific dairy - a possibility given the preexistence of ADs at dairies prior to the establishment of GHG credit markets-the GHG credits might not be considered additional, because no actual change in practice would occur to generate the credits. Because of the path dependence illustrated in Table 2, contemporaneous stacking presents difficulties in determining which credit streams are non-additional; with temporal stacking, it is easier to flag such streams as non-additional. ${ }^{3}$

Fixed versus variable environmental benefits. In the stacking example above, it is assumed that the technology produces environmental benefits in fixed proportions. This may not be the case for nutrient reductions achieved with AD. Substantial nutrient removal may require a process separate from anaerobic digestion to further reduce $\mathrm{N}$ loadings, thereby generating incremental nutrient reduction benefits, but at an incremental cost. In this case, the conditions under which stacking is acceptable may include a nutrient credit payment to cover the cost of the separate nutrient production process. If so, allowing full stacking of all credits may present no additionality problem.

Temporal, horizontal, and vertical stacking are not discussed in crediting programs reviewed in this article. The California cap-and-trade regulatory compliance protocol for GHG offsets does not mention stacking. However, the CAR has been trying to tackle the stacking issue since 2011, when it formed its Credit Stacking Subcommittee. Currently, only the CAR Nitrogen Management offset protocol (CAR, 2013b) mentions stacking, but only the credit and payment stacking forms of the issue. The protocol does not comment on the former, but it provides detailed analyses of stacking where government payments are used for financing. Because most environmental payment systems have developed independently of one another, changes in their structures are likely needed to achieve a more streamlined system of environmental markets (WRI, 2014).

\footnotetext{
${ }^{3}$ However, it is conceivable that the project investor could claim that it is the expectation of a GHG credit market materializing that caused them to invest in $\mathrm{AD}$, thereby claiming that the GHG credit should be additional. There is no case law that we know of that addresses this issue.
} 


\section{Discussion}

A unique constellation of market opportunities presents itself to CAFOs, particularly dairies, adopting AD. First, in these food production systems, revenues from environmental markets may be treated differently than traditional goods because additionality and stacking need specific consideration only in environmental markets. There are important differences between traditional goods and environmental goods, like GHG reductions. The former arises from purely innate preferences for given products, the associated willingness to pay for those attributes, and the technology and costs to produce them, all of which determine a market price and quantity. The role of government in these markets is primarily limited to ensuring that production occurs safely, dependably, and competitively.

Environmental goods, such as GHG reductions, are public goods, which means that they typically lack "natural" markets to facilitate their exchange (Keohane \& Olmstead, 2016). Inherent problems such as lack of excludability and nonrival consumption lead to free-riding, which makes it difficult to create and sell GHG reductions in a private setting. As such, pollution control usually occurs through a regulatory mandate. That is the case here, with one further twist: an environmental credit generated through $\mathrm{AD}$ adoption can be sold to another party using the credit as a right to pollute elsewhere (an "offset" [Murray, 2010]). Therefore, if the action underlying the credit does not lead to a real pollution reduction, allowing the credit transfer to occur will lead to an unintended increase in pollution rather than to a net-zero change. Prudent efforts to ensure that reductions are additional to what would have occurred anyway are important to protect the environmental integrity of the exchange.

Second, it may be difficult to determine whether a digester should be given credit for all of the methane and GHGs captured or only the methane and greenhouse gases that would have been emitted if the digester had not been used. The general notion of crediting an action for its level of emissions reduction is that it captures a level of emissions that is lower than if the action had not been taken. But what would have happened other- wise? Under AD adoption, the most reasonable assumption is that the "conventional" forms of waste management would have been undertaken (e.g., solids separation, land application). Therefore, what should be credited is the net difference in methane and other GHG emissions under an AD and an estimate of those emissions under conventional management. Crediting all GHGs captured under an $\mathrm{AD}$ would only make sense if all those GHGs would have ended up in the atmosphere if conventional practices were followed.

However, ADs can be accompanied by complicating factors. ADs capture a higher percentage of methane relative to conventional anaerobic nonAD systems, such as anaerobic lagoons, so the reductions are presumably creditable if a conventional anaerobic technology would otherwise have been used. However, if the otherwise-used technology had been an aerobic system, little to no methane would have been generated, so there would be little to no emissions to reduce. In this case, $\mathrm{AD}$ is only capturing the methane that the alternative (aerobic) technology would not have generated. As such, no real emissions reduction occurs. Based on the CAR protocol, the baseline emissions equal those from an anaerobic system used before AD adoption. Thus, if an aerobic system had been used, no methane would have been generated, and no credits would be issued after AD adoption. There are also intermediate cases; for instance, co-digesting manure with solids (e.g., straw) that would not have been broken down anaerobically in a conventional system lowers the amount of emissions reduction attainable by the AD.

A third issue arises around the number of nutrient credits generated. A digester potentially could earn nutrient credits for all of the nutrients captured on-site and not applied to land near an impaired watershed. However, a complication arises when the producer using that digester imports fertilizer to replace the removed nutrients, or if the removed nutrients are just applied to land elsewhere in the watershed. As with the question on the scope of GHG credit, AD—specifically the nutrient removal technology-should in principle earn nutrient credits for the difference in nutrient loadings relative to the WLA without the AD. For 
example, if manure is now processed by an $\mathrm{AD}$ and nutrients are removed by a separate process rather than land applied, the avoided loadings relative to the WLA from land application, in principle, are creditable. However, a consistent approach would, at a minimum, consider the net change in loadings from the whole CAFO system. Thus, if imported fertilizers are now land applied in lieu of manure on the CAFO property, which used to apply manure at agronomic rates (e.g., to grow feed), loadings from those fertilizers should also be included in the credit calculation. It may still be the case that the loadings from fertilizer application are less than those from manure application, making for a net improvement, but the credits should be reduced by any loadings that will occur in the new system.

Matters are more complicated when nutrients from the $\mathrm{AD}$ are applied to land outside the boundaries of the CAFO property, leading to concerns of spillover effects (leakage) if pollution is simply displaced. If the nutrients are applied on lands subject to NPDES permitting, the loadings are controlled—or at least are controllable—and spillovers are less of a concern. If nutrients are applied on lands not subject to NPDES permitting, there may be spillover effects to consider. If the land is not subject to NPDES permitting because it is in an unimpaired watershed, spillover concerns may be minimized. However, spillover effects at a scale large enough to transform unimpaired watersheds into impaired watersheds would clearly be a problem. One solution is more careful monitoring of loadings on all watersheds, but that has a cost. Another solution would be to avoid overapplication by requiring nutrient management plans for farms that receive nutrients from an AD. Policymakers should weigh the benefits of nutrient trading against the potential risks to currently unimpaired watersheds and the costs of enhanced monitoring to make a reasoned decision.

\section{Conclusion}

Stacking of environmental credits can create problems in an offset crediting system when the technology of interest (here, AD) jointly produces multiple creditable benefits (Robertson et al., 2014). The problem occurs when credits are assigned for some benefits that would be produced anywaythe non-additionality problem-as when AD adoption is profitable only if a subset of the benefits are paid for, thereby generating the extra benefits "for free." Any credits issued for the free benefits are problematic if they allow the credit buyer to pollute more. Solutions to this situation are difficult because the baseline to which actual performance is compared is often a counterfactual—something that did not occur or will not occur, but represents an estimate of what would have occurred if the payments were not made. Moreover, with the multiple credits at issue in stacking, the path dependency and sequencing of payments make the additionality determination of single-credit payments particularly challenging. Because of this difficulty, environmental protocols have largely sidestepped the issue. The main difficulty is the arbitrary assignment of crediting streams for purely joint production technologies; which benefit streams come first? If each type of credit can be generated only with incremental effort and cost, additionality is less of a problem because the revenue from the additional credits can be compared to that cost.

Until ecological trade-offs among ESs are better understood, stacking should be used with caution (Robertson et al., 2014). Currently, no regulations or U.S. federal resource agencies address stacking in these farm systems or any other system. In light of this, Robertson et al. (2014) propose that stacked credits from a given site be sold only within an area having the same environmental regulatory background. One specific solution to the stacking problem in the case of ADs may be to allow stacking of all credits available at the time of $\mathrm{AD}$ installation, but to prohibit any further stacking if new credit streams become available after installation. The rationale for this approach is that additional elements cannot be separated from nonadditional elements at inception because they are contemporaneous, but that non-additionality can be inferred if new credits are made available in the future for benefits that are being generated from the start. Although some non-additional credits might be allowed in this way, this error of commission must be measured against errors of omission-legitimate AD projects left out if stacking is not allowed (Woodward, 2011). Protocols should 
consider discounting (issuing partial credit) as a way to address concerns of overcrediting in these situations without eliminating potentially legitimate projects altogether.

In principle, the additionality challenge with stacking could be addressed through further pilottesting of $\mathrm{AD}$ operations under a wide range of geographic and production system characteristics and subject to an array of environmental payment options. This would require more seed financing for constructing the AD pilot tests and greater availability of environmental market payments for
GHGs and nutrient credits. Private investors could provide finance, but only if they had the sense that environmental markets would proliferate to cover their costs and reward their efforts. These markets could be driven by flexible compliance to government mandates for nutrients and GHGs, but these may not be inevitable under the current political circumstances. Alternatively, sustainable food supply-chain standards might be a way to provide further incentives for the adoption of $\mathrm{AD}$ and other practices that have multiple benefits for food production and the environment.

\section{References}

Arvanitoyannis, I. S., \& Giakoundis, A. (2006). Current strategies for dairy waste management: A review. Critical Reviews in Food Science and Nutrition, 46(5), 379-390. https://doi.org/10.1080/10408390591000695

Barbose, G. L. (2018). U.S. renewables portfolio standards: 2018 annual status report. Berkeley, CA: Lawrence Berkeley National Lab. https://doi.org/10.2172/1393633

Climate Action Reserve [CAR]. (2009). Livestock calculation tool (Beta ver. 2.1.3). Retrieved October 10, 2014, from http://www.climateactionreserve.org

CAR. (2013a). U.S. livestock project protocol (Ver. 4.0). Retrieved November 22, 2014, from http://www.climateactionreserve.org/wpcontent/uploads/2009/03/U.S. Livestock Project Protocol V4.0 Package 012114.pdf

CAR. (2013b). Nitrogen management project protocol. Retrieved November 22, 2014, from http://www.climateactionreserve.org/how/protocols/nitrogen-management

Douglas, R. (2012). How to generate tradable nutrient reduction credits. BioCycle, 53(6), 48-51. https://www.biocycle.net/2012/06/14/how-to-generate-tradable-nutrient-reduction-credits/

Frear, C., \& Dvorak, S. (2012). Anaerobic digestion and nutrient recovery. Presentation at AgStar National Conference, Syracuse, NY. http://www.epa.gov/agstar/documents/conf12/10b_Dvorak-Frear.pdf [No longer available online]

Hoover, J. N. (2013). Can't you smell that smell? Clean Air Act fixes for factory farm air pollution. Stanford Journal of Animal Law and Policy, 6, 1-29. https://law.stanford.edu/stanford-journal-of-animal-law-and-policy-sjalp/

ICF International [ICF]. (2013). Greenhouse gas mitigation options and costs for agricultural land and animal production within the United States. Washington, D.C.: U.S. Department of Agriculture. Retrieved from https://www.usda.gov/oce/climate_change/mitigation_technologies/GHGMitigationProduction_Cost.htm

Informa Economics. (2013, February). National market value of anaerobic digester products [PowerPoint presentation]. Retrieved from https://www.slideshare.net/JerryBingold/national-market-potential-of-anaerobic-digester-productsfor-the-dairy-industry-40113-60864699

Keohane, N. O., \& Olmstead, S. M. (2016). Markets and the environment (2 ${ }^{\text {nd }}$ Ed). Washington, D.C.: Island Press. https://doi.org/10.5822/978-1-61091-608-0

Lazarus, W. F. (2008). Farm-based anaerobic digesters as an energy and odor control technology. Background and policy issues (Agricultural Economic Report No. 843). Washington, D.C.: USDA Office of Energy Policy and New Uses. Retrieved from http://www.usda.gov/oce/reports/energy/AnerobicDigesters0308.pdf

Lee, H., \& Sumner, D. A. (2014). Greenhouse gas mitigation opportunities in California agriculture: Review of the economics (Report No. NI GGMOCA R7). Durham, N.C.: Nicholas Institute, Duke University. Retrieved from https://aic.ucdavis.edu/publications/california $\% 20$ economics $\% 20$ for $\% 20$ GHG $\% 20$ dduke $\% 20$ report.pdf

Ma, J., Kennedy, N., Yorgey, G., \& Frear, C. (2013). Review of emerging nutrient recovery technologies for farm-based anaerobic digesters and other renewable energy systems. Retrieved from http://csanr.wsu.edu/wpcontent/uploads/2014/07/ICUSD-Emerging-NR-Technology-Report-Final.121113B.pdf 
Merkel, M. M. (2006). EPA and state failures to regulate CAFOs under federal environmental laws. Environmental Integrity Project [EIP]. http://www.environmentalintegrity.org/pdf/publications/EPA State Failures Regulate CAFO.pdf

Miller, D. L., \& Muren, G. (2019). CAFOs: What we don't know is burting us (Report no. R:19-06-A). National Resources Defense Council (NRDC). Retrieved January 15, 2020, from https://www.nrdc.org/sites/default/files/cafos-dont-know-hurting-us-report.pdf

Murray, B. C. (2010). Emissions offsets in a greenhouse gas cap-and-trade policy. In I. W. H. Parry \& F. Day (Eds.), Issues of the Day: 100 Commentaries on Climate, Energy, the Environment, Transportation, and Public Health Policy (pp. 30-31). Washington, D.C.: RFF Press.

Murray, B. C., Galik, C. S., \& Vegh, T. (2017). Biogas in the United States: Estimating future production and learning from international experiences. Mitigation and Adaptation Strategies for Global Change, 22, 485-501. https://doi.org/10.1007/s11027-015-9683-7

Myhre, G., Shindell, D., Bréon, F.-M., Collins, W., Fuglestvedt, J., Huang, J., . . Zhang, H. (2013). Anthropogenic and natural radiative forcing. In T. F. Stocker, D. Qin, G.-K. Plattner, M. Tignor, S. K. Allen, J. Boschung, . . P. M. Midgley (Eds.), Climate Change 2013: The Physical Science Basis: Contribution of Working Group I to the Fifth Assessment Report of the Intergovernmental Panel on Climate Change (pp. 659-740). Cambridge \& New York: Cambridge University Press. Retrieved from https://www.ipcc.ch/report/ar5/wg1/

North Carolina Cooperative Extension. (2012). Types of anaerobic digesters [Factsheet]. Accessed 3/13/2015. http://www.extension.org/pages/30307/types-of-anaerobic-digesters/

North Carolina General Statutes $\ 62-133.8(a)(6)$. (2014). Retrieved from https://www.ncleg.net/enactedlegislation/statutes/html/bysection/chapter 62/gs 62-133.8.html

Pfost, D. L., \& Fulhage, C. D. (2000). Anaerobic lagoons for storage/treatment of livestock manure. Columbia: MU Extension, University of Missouri-Columbia. Retrieved from http://extension.missouri.edu/explorepdf/envqual/eq0387.pdf

Regional Greenhouse Gas Initiative [RGGI]. (2013). Model rule. https://www.rggi.org/program-overview-and-design/design-archive/mou-model-rule

Robertson, M., BenDor, T. K., Lave, R., Riggsbee, A., Ruhl, J. B., \& Doyle, M. (2014). Stacking ecosystem services. Frontiers in Ecology and Environment, 12(3), 186-193. https://doi.org/10.1890/110292

Smith, V. H., Tilman, G. D., \& Nekola. J. C. (1999). Eutrophication: Impacts of excess nutrient inputs on freshwater, marine, and terrestrial ecosystems. Environmental Pollution, 100(1-3), 179-196. https://doi.org/10.1016/S0269-7491(99)00091-3

U.S. Bureau of Labor Statistics [U.S. BLS]. (n.d.). CPI calculator. Retrieved October 15, 2014, from http://www.bls.gov/data/inflation calculator.htm

U.S. Energy Information Administration [U.S. EIA]. (2016). Henry hub natural gas spot price. Retrieved February 16, 2016, from https://www.eia.gov/dnav/ng/hist/rngwhhdd.htm

U.S. Environmental Protection Agency [U.S. EPA]. (2003). Appendix B: US EPA Office of Water, water quality trading policy. Retrieved November 6, 2014, from http://water.epa.gov/type/watersheds/trading/finalpolicy2003.cfm [No longer available online]

U.S. EPA. (2008a). CAFO final rule 2008. Retrieved July 14, 2014, from http://water.epa.gov/polwaste/npdes/upload/cafo final rule2008 comp.pdf [No longer available online]

U.S. EPA. (2008b). Renewable energy certificates. Retrieved September 14, 2014, from http://www.epa.gov/greenpower/documents/gpp basics-recs.pdf [No longer available online]

U.S. EPA. (2010). U.S. Anaerobic digester status report. Retrieved November 13, 2014, from http://www.epa.gov/agstar/documents/digester_status_report2010.pdf [No longer available online]

U.S. EPA. (2014). Anaerobic digesters. Retrieved March 13, 2015, from http://www.epa.gov/agstar/anaerobic/ad101/anaerobic-digesters.html [No longer available online]

U.S. EPA. (2019a). U.S. Livestock anaerobic digester database. Retrieved March 20, 2019, from https://www.epa.gov/agstar/livestock-anaerobic-digester-database

U.S. EPA. (2019b). Renewable energy certificates (RECs). Retrieved January 15, 2020, from https://www.epa.gov/greenpower/renewable-energy-certificates-recs\#certificate 
U.S. EPA AgSTAR Program. (2012). Funding on-farm anaerobic digestion. Retrieved from https://www.epa.gov/agstar/funding-farm-anaerobic-digestion

U.S. EPA AgSTAR Program. (2018). AgSTAR data and trends. Retrieved February 19, 2019, from https://www.epa.gov/agstar/agstar-data-and-trends

U.S. Government Accountability Office [U.S. GAO]. (2008). Concentrated animal feeding operations: EPA needs more information and a clearly defined strategy to protect air and water quality from pollutants of concern (Report No. GAO-08-944). Retrieved from http://www.gao.gov/new.items/d08944.pdf

U.S. Department of Agriculture [USDA]. (2009). News release No. 0613.09. http://www.usda.gov/wps/portal/usda/usdamediafb? contentid=2009/12/0613.xml [No longer available online]

USDA. (2019). 2017 Census of Agriculture: United States summary and state data, Volume 1, Geographic Area Series, Part 51. Retrieved from https://www.nass.usda.gov/Publications/AgCensus/2017/Full Report/Volume 1, Chapter 1 US/usv1.pdf

USDA Natural Resources Conservation Service [USDA NRCS]. (1992). Agricultural waste management handbook. Retrieved from http://www.nrcs.usda.gov/wps/portal/nrcs/detailfull/national/water/?\&cid=stelprdb1045935

Van Horn, H. H., Wilkie, A. C., Powers, W. J., \& Nordstedt, R. A. (1994). Components of dairy manure management systems. Journal of Dairy Science, 77, 2008-2030. https://doi.org/10.3168/jds.S0022-0302(94)77147-2

Verified Carbon Standard. (2013). Guidance for standardized methods (8 October 2013, ver. 3.3). Retrieved from http://verra.org/wp-content/uploads/2018/03/VCS-Guidance-Standardized-Methods-v3.3 0.pdf

Woodward, R. T. (2011). Double-dipping in environmental markets. Journal of Environmental Economics and Management, 61(2), 153-169. https://doi.org/10.1016/j.jeem.2010.07.004

World Resources Institute [WR]. (2014). How can conservation programs effectively interact with environmental markets? Retrieved from http://www.usda.gov/oce/environmental markets/files/WRI Conservation $\% 20$ Programs $\% 20$ and $\% 20$ Env $\% 20 \% 20$ Markets.pdf

Yiridoe, E. K., Gordon, R., \& Brown, B. B. (2009). Nonmarket cobenefits and economic feasibility of on-farm biogas energy production. Energy Policy, 37(3), 1170-1179. https://doi.org/10.1016/i.enpol.2008.11.018 